\title{
Surface energy exchange and evapotranspiration from cotton crop under full irrigation conditions in the Rio Grande do Norte State, Brazilian Semi-Arid
}

\author{
Bergson Guedes Bezerra ( $\left.{ }^{1 *}\right)$; José Renato Cortez Bezerra ( $\left.{ }^{2}\right)$; Bernardo Barbosa da Silva (3); \\ Carlos Antonio Costa dos Santos $\left({ }^{4}\right)$
}

(') Universidade Federal do Rio Grande do Norte (UFRN), Programa de Pós-Graduação em Ciências Climáticas, Avenida Senador Salgado Filho, 3.000, 59078-970 Natal (RN), Brasil.

(2) Embrapa Algodão, Rua Oswaldo Cruz, 1.143, 58428-095 Campina Grande (PB), Brasil.

(3) Universidade Federal de Pernambuco (UFPE), Departamento de Ciências Geográficas, Av. Prof. Moraes Rego, 1.235, 50670-901 Recife (PE), Brasil.

(4) Universidade Federal de Campina Grande (UFCG), Departamento de Ciências Atmosféricas, Rua Aprígio Veloso, 882, 58429-900 Campina Grande (PB), Brasil.

${ }^{*}$ ) Corresponding author: bergson@ccet.ufrn.br

Received: Aug. 1, 2014; Accepted: Nov. 17, 2014

\begin{abstract}
The main objectives of this study were documenting how energy balance partitioning and ET vary seasonally along each growth season of cotton crop under full irrigation conditions in the Brazilian semiarid. The studied area was located in the Apodi Plateau, which is located on west of Rio Grande do Norte state and is an area with extensive agricultural suitability and semiarid climate. Micrometeorological measurements were taken during cotton growth season on dry seasons of 2008 and 2009 years in a cotton crop field of about 5 ha, and the energy balance components were derived from Bowen Ratio Energy Balance (BREB) method. The obtained results revealed important role of the vegetative growth of cotton crop in the energy balance partitioning. The values of LE/Rn ranged from 58\% (Initial growth season) to 81\% (Middle-growth season) in 2008 and from 63\% (Initial) to $81 \%$ (Middle season) in 2009. These variations is in accordance to LAl variations, which ranged from $0.14 \mathrm{~cm}^{2} \mathrm{~cm}^{-2}$ (Initial growth season in 2008) and $0.18 \mathrm{~cm}^{2} \mathrm{~cm}^{-2}$ (Initial growth season in 2009) to about $5.0 \mathrm{~cm}^{2} \mathrm{~cm}^{-2}$ (middle season). On the other hand, $\mathrm{H} / \mathrm{Rn}$ and $\mathrm{G} / \mathrm{Rn}$ varied inversely with the LAl variations. The concordance between LE/Rn and LAl is evidenced by similarity between curves of ET and LAl and between curves of Kc and LAl, especially when LAl reaches values greater than 3.0.
\end{abstract}

Key words: Bowen ratio; energy balance, LAl.

\section{INTRODUCTION}

The cotton crop in the 20th century was the main agricultural and economic activity of Brazilian Semi-Arid. However in the mid-80's the cropping of cotton activity was virtually extinct. The decrease of this crop is attributed to inability of production system which was not equipped with appropriate technology to overcome problems such as competition with subsidized prices in the international market, end of import duties for imported fiber and management of the boll weevil (Anthonomus grandis) plague that has proliferated in the region (Bezerra et al., 2010, 2012). The production system was rudimentary and based on the family farming. The used cultivar is locally called as "mocó" (Gossipium hirsutum marie galante Hutch.), arboreal and perennial whose production cycle was about five years, cultivated always intercropped with other crops such as maize and beans under rainfed conditions. These crop management options resulted low yield from $200 \mathrm{~kg}$ $\mathrm{ha}^{-1}$ to $300 \mathrm{~kg} \mathrm{ha}^{-1}$. Thus, the agricultural activity became uncompetitive, unsustainable, and naturally collapsed.

The recovery of cotton growing is very important to the economy of Brazilian semiarid. However, new technologies should be adopted in order to modernize the production system and abolish past practices. In the recent years efforts have been made to develop these technologies such as breeding of cultivars adapted to the climatic conditions of semiarid with growth stages shorter and compatible with rainy season length and able to provide highest yield. These new technologies have provided substantial improvements in the production system, so that the cotton yield has reached values greater than 3,000 $\mathrm{kg} \mathrm{ha}^{-1}$ (Bezerra et al., 2012). 
The recovery of cotton cultivation has been noticed on some areas of the Brazilian semi-arid but the cropping is based on agribusiness under irrigated conditions. Production under irrigated conditions enables the yield maximization, reduction of risks arising from rainfall variability and the possibility of obtaining a better quality fiber (Bezerra et al., 2010). However, it requires appropriate irrigation scheduling because water is scarce, especially in arid and semi-arid regions. Several studies have been development in Brazilian semi-arid seeking the best water-soil-plant-atmosphere relations for cotton to provide water use efficiency (Azevedo et al., 1993; Bezerra et al., 2010, 2012). These water-soil-plant-atmosphere relations for cotton crop should be determined in detail for various areas of the Brazilian Semi- arid because it is a region with great variability of soils and climate (e.g., rainfall, air humid, soil and air temperature) (Bezerra et al., 2012).

The most fundamental requirement of scheduling irrigation and appropriate agricultural water management is accurate calculation of crop evapotranspiration (ET). The cotton ET has been obtained from several methodologies such as soil water balance (Farahani et al., 2008), lysimeter (Azevedo et al., 1993), and micrometeorological methods (Bezerra et al., 2010, 2012; Zhou et al., 2012). The Bowen Ratio Energy Balance (BREB) method is a practical and relatively reliable micrometeorological method based on the BREB concept (Bowen, 1926) which enables solving the energy balance equation (Allen et al., 2011). The BREB method is often used because of the simplicity of data collection, and because the robust nature of the system allows for long-term data acquisition (Perez et al., 1999).

The partitioning of net radiation into exchanges of sensible, latent and soil heat fluxes (energy balance) is controlled by factors such as climate, land cover characteristics, hydrological and biochemical processes on the land surface, water management, morphology and physiology of a given crop under specific meteorological conditions and plays a dominant role in the occurrence of soil moistureprecipitation or irrigation feedback (Baldocchi, 2003). Ordinarily, latent heat flux or ET is the largest consumer of available solar energy especially in irrigated agriculture consuming $60-80 \%$ of net radiation in a growing season (Suyker \& Verma, 2008). The ET process is controlled by several interacting biophysical and environmental factors including soil moisture, canopy conductance, leaf area, net radiation, temperature, vapor pressure deficit, and wind speed (Alberto et al., 2011).

The main objectives of this study were documenting how energy balance partitioning and ET vary seasonally along each growth season of cotton crop under full irrigation conditions in the Brazilian semiarid.

\section{MATERIAL AND METHOD}

\section{Experimental site, climate and soil}

The studied site was located in the Apodi Plateau, west of Rio Grande do Norte state, Brazilian Semi-Arid region (Figure 1). The climate of the region is semi-arid (Bezerra et al., 2012). It is high availability of light resource with annual total sunshine duration over 3,000 $\mathrm{h}$. The average annual rainfall range from about 700 to about $1,000 \mathrm{~mm}$, but presents high atmospheric water demand with mean annual pan evaporation about $2,100 \mathrm{~mm}$. The relief presents a great uniformity with slopes less than $2 \%$ which is highly favorable to agricultural mechanization. The groundwater is the main source of water for irrigation, which is pumped out from

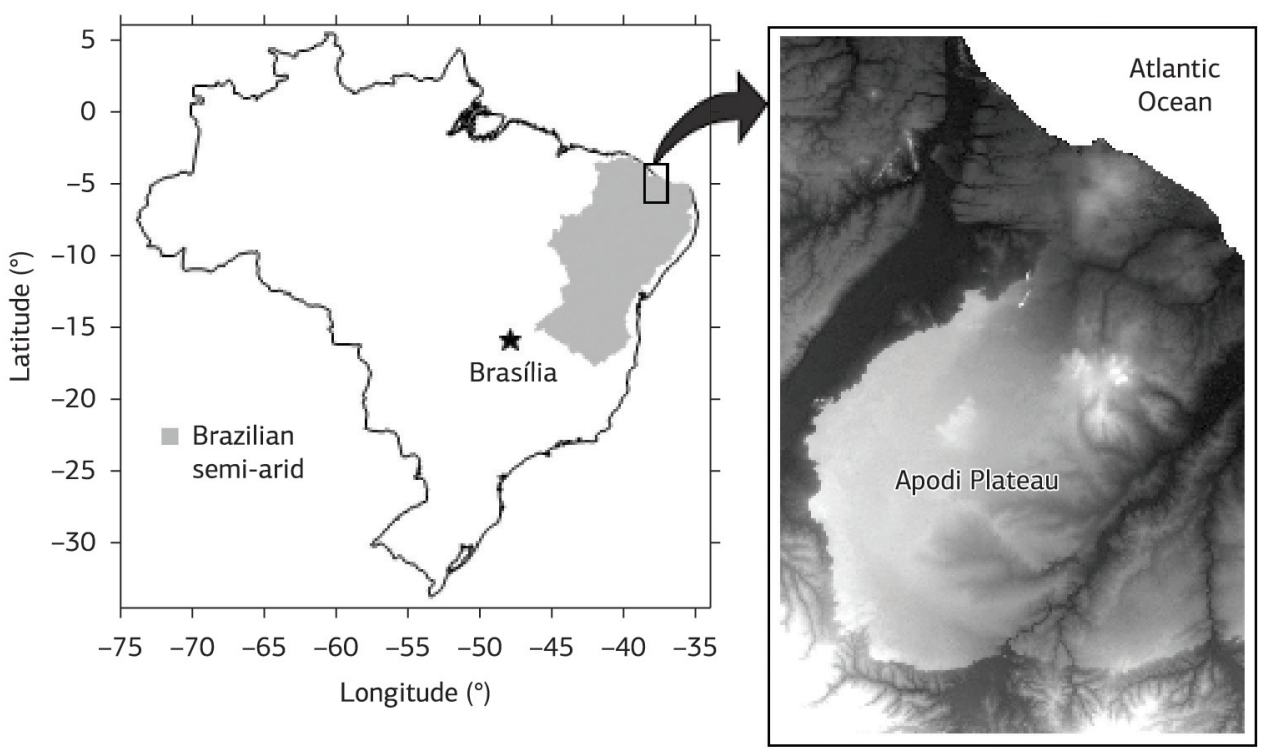

Figure 1. Location map of study site, Apodi Plateau, in the Brazilian semiarid. 
Jandaíra calcareous aquifer through wells of about $100 \mathrm{~m}$ depth (Bezerra et al., 2012). According to Bezerra et al. (2012) the predominant soils in the area are Cambisoil.

The experiment was carried out in the Experimental Station of the Agricultural Research Company of Rio Grande do Norte State (EMPARN) located in Apodi county (5 $37^{\prime} 37^{\prime \prime}$, $37^{\circ} 49^{\prime} 54^{\prime \prime} \mathrm{W}, 138 \mathrm{~m}$ above sea level). The soil texture of experimental area is sandy-clay-loam, according to USDA (United States Department of Agriculture) classification, with a porosity of $56 \%$ and presents field capacity $\left(\theta_{\mathrm{FC}}\right)$ equal to $0.32 \mathrm{~cm}^{3} \mathrm{~cm}^{-3}$ and permanent wilting point $\left(\theta_{\mathrm{PWP}}\right)$ equal to $0.13 \mathrm{~cm}^{3} \mathrm{~cm}^{-3}$. More details about study the area can be found in Bezerra et al. (2012).

\section{Crop and measurements}

The study was carried during dry seasons (from August to December) of 2008 and 2009 years in a cotton crop field of about 5 ha ( $230 \mathrm{~m}$ along and $230 \mathrm{~m}$ wide). The studied cultivar was BRS $1878 \mathrm{H}$ which results from crossing between cultivar CNPA 77/105, resistant to root borer (Eutinobothrus Hanabol brasiliensis) and D3-79 lineages, of U.S. origin (CNPA, 2000). The cotton crop was sown at $0.9 \mathrm{~m}$ row spacing and linear density of 10 plants per meter, totaling about 133,000 plants by hectare. The crop was fully irrigated using a sprinkler irrigation system three times per week. The irrigation system presented Christiansen's uniformity coefficient (CU) equal to $84.7 \%$. The irrigation was scheduled using FAO-56 methodology. More details about irrigation management can be found in Bezerra et al. (2012).

The leaf area index (LAI) was measured every 15 days from $15^{\text {th }}$ day after emergency (DAE) to $93^{\text {th }} \mathrm{DAE}$ in 2008 and $105^{\text {th }} \mathrm{DAE}$ in 2009 , from leave area measurement. The measurements were obtained using leaf area meter model LI3100-C (LI-COR Environmental, Lincoln, NB). Six plants were collected and individual area of each leaf was measured. The LAI values were obtained by integrating the area of all leaves of each plant, divided by the density of the plants.

The micrometeorological tower equipped with a Bowen Ratio Energy Balance (BREB) system was set up to record measurements of energy balance fluxes at the interface between cotton/soil system and the atmosphere during cotton growth season. The distance from tower to field boundary was approximately $140 \mathrm{~m}$ in the predominant wind direction (southeast) in order to provide sufficient fetch $\left(\mathrm{x}_{\mathrm{f}}\right)$ required by BREB method (Brutsaert, 1982; Peacock $\&$ Hess, 2004), according to following equation (Brutsaert, 1982; Peacock \& Hess, 2004):

$x_{f}=\left[\frac{30(z-d)}{z_{0}^{0.125}}\right]^{1.14}$ where $\mathrm{z}(2,5 \mathrm{~m})$ is maximum sensor height, $\mathrm{d}(\mathrm{m})$ is the zero plane of displacement and $z_{0}(m)$ is the surface roughness length of momentum. The values of $d$ and $z_{0}$ were calculated using the equations given by Brutsaert (1982):

$d=0.67 h$

$z_{0}=0,123 h$

Net radiation (Rn) and soil heat flux (G) were directly measured using a net radiometer model NR-LITE (Kipp $\&$ Zonen, Delft, The Netherlands) installed $2 \mathrm{~m}$ above cotton canopy and two soil heat flux plates model HFP01 (Hukselfux Thermal Sensors, Delft, The Netherlands), one inter-row and other inter-plants, buried at $0.02 \mathrm{~m}$ soil depth, respectively. Dry and wet bulb temperatures were measured using psychrometers constructed with thermocouples type $\mathrm{T}$ (copper-constantan), installed at 0.5 and $2.0 \mathrm{~m}$ above canopy. The wind speed was measured at two heights (same heights of psychrometers) using 3-cup anemometer model 03101 (R.M. Young Copany, Traverse City, MI, USA). The height of psycrometers, anemometers, and net radiometer was adjusted weekly following the change in plant height. All these sensors were previously calibrated and connected to a CR3000 datalogger (Campbell Sci. Inc., Logan, UT). Data were sampled every $5 \mathrm{~s}$, and 20-min averages were obtained and stored.

Daily values of wind speed at $2 \mathrm{~m}$ height, maximum and minimum air temperatures, maximum and minimum relative humidity and daily total incoming solar radiation were used to estimate reference evapotranspiration $\left(\mathrm{ET}_{0}\right)$ by Penmann-Monteith method standardized in FAO Irrigation and Drainage Paper No. 56 (Allen et al., 1998). These weather variables were measured in the meteorological station of Apodi-RN, nearer to the cotton field (in a distance of $300 \mathrm{~m}$ ).

\section{Bowen ratio energy balance method}

The Bowen Ratio Energy Balance (BREB) is a commonly micrometeorological method used to estimate latent heat flux from energy balance equation (Equation 4) and calculated evapotranspiration. Neglecting energy storage in the canopy and photosynthetic energy flux, as they represent less than $2 \%$ of net radiation, the energy balance of cotton crop is expressed by means of bulk energy and heat fluxes (Perez et al., 1999; Teixeira \& Bastiaanssen, 2012).

$$
R n=L E+H+G\left(W m^{-2}\right)
$$

where $\mathrm{Rn}$ is net radiation above the cotton canopy, LE is latent heat flux from cotton crop, $\mathrm{H}$ is sensible heat flux from cotton crop, and G is soil heat flux. The LE values were derived from energy balance equation (Equation 1) and Bowen ratio concept (Allen et al., 2011; Bowen, 1926): 


$$
L E=\frac{R n-G}{1+\beta}\left(W m^{-2}\right)
$$

where $\beta=\gamma(\Delta T / \Delta e)$ is so-called Bowen ratio, where $\gamma$ $\left(\mathrm{kPa}{ }^{\circ} \mathrm{C}^{-1}\right)$ is the psychrometric constant, $\Delta \mathrm{T}$ and $\Delta \mathrm{e}$ above canopy verticals gradients of air temperature $\left({ }^{\circ} \mathrm{C}\right)$ and vapor pressure $(\mathrm{kPa})$, respectively.

The cotton ET was calculated by dividing LE by latent heat of vaporization. Following Perez et al. (1999), only the observed data during daytime periods $(\mathrm{Rn}-\mathrm{G}>0)$ were studied. When temperature and vapour pressure gradients are in opposite directions, according to sign of $\mathrm{Rn}-\mathrm{G}$, this can lead to calculations of $\mathrm{H}$ and $\mathrm{LE}$ that are inconsistent with the energy balance equation (Peacock \& Hess, 2004). According to Peacock \& Hess (2004), the BREB method fails and the data must be discarded in this case. According to Perez et al. (1999) the data discarded correspond to the night-time period and to precipitation or irrigation events. For these reasons the irrigation events in this study always occurred during the night. The Sensible heat flux $(\mathrm{H})$ was obtained forcing energy balance closure (Teixeira $\&$ Bastiaanssen, 2012) i.e., as a residual in Equation 4.

To avoid errors in the estimation of the BREB fluxes, data when $-1.25<\beta<-0.75$, when values for which the measurements of gradients of temperatures and vapor pressure were lower than the resolution limit of the sensors, and when the wind speed at the upper height was lower than $1.0 \mathrm{~m} \mathrm{~s}^{-1}$ and the difference of the wind speed between both heights was lower than $0.3 \mathrm{~m} \mathrm{~s}^{-1}$ of the sensors were eliminated (Payero et al., 2003). Each eliminated value was replaced by interpolation between two values that preceded and followed the eliminated value.

The partitioning of the available energy balance can be evaluated by analyzing the dimensionless evaporative fraction $(\Lambda)$, defined as a ratio of latent heat flux to available energy flux, it is usually used to characterize the energy partition over the land surface (Shen et al., 2004),

$\Lambda=\frac{L E}{R n-G}$

\section{RESULTS AND DISCUSSION}

\section{Weather conditions}

Average monthly air temperatures (Tair) along with 30-year normals for the months in which the experimental campaigns were carried out is shown in figure 2 . The cotton growing season of the 2008 year was about $1.5^{\circ} \mathrm{C}$ warmer than the normal while the cotton growing season of the 2009 year was almost $1^{\circ} \mathrm{C}$ warmer than the normal. The average monthly relative humidity $(\mathrm{RH})$ values (Figure 2 ) indicate that cotton growing season in both 2008 and 2009

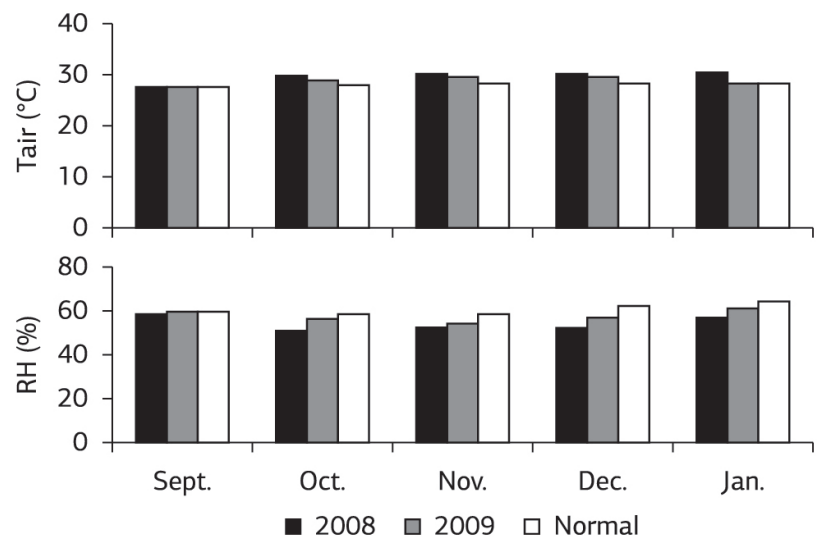

Figure 2. Average monthly air temperature at the study area during growing season of both 2008 and 2009 years compared to 30-year normal and average monthly relative humidity at the study area during growing seasons of both the 2008 and 2009 years compared to 30 -year normal. The 30 -year normals belong to the Apodi-RN meteorological station.

years was drier than the normal. The growing season of the 2008 was about $9 \%$ drier than the normal while that of the 2009 year was only $2.8 \%$ drier than normal.

The cotton growing season of the 2008 was almost $1.0{ }^{\circ} \mathrm{C}$ warmer than 2009 and this temperature difference was determinative on growth season length which in 2008 was 7 days shorter than 2009 (Table 1). The accumulated Growing-Degree-Days (GDD), which was calculated using the standard method (Mavi \& Tupper, 2004), evidences this effect, whose value was around $1,500{ }^{\circ} \mathrm{C}$ (Table 1 ). According to Mavi \& Tupper (2004) the GDD is a simple means of relating plant growth, development, and maturity to air temperature. The GDD concept assumes a direct and linear relationship between growth and temperature and has been often used in agronomy, essentially to estimate or predict the lengths of the different growth seasons of crops (Farahani et al., 2008; Howell et al., 2004). Defining events related to crop growth such as growth season length and crop coefficient based on GDD scale improves intersite and interseasonal transferability (Howell et al., 2004).

\section{Energy exchange and evapotranspiration}

The irrigation water supplied to cotton crop in Apodi during each crop growth season in both 2008 and 2009 years is shown in table 2 . The difference between irrigation amount of 2008 and 2009 were attributed to growth season length (Bezerra et al., 2012). During cotton crop growth season of 2008 there was no rainfall. During Late-season in 2009 the rainfall was $18.6 \mathrm{~mm}$.

As can be seen in table 2 the variations of energy balance partitioning agree with variations of LAI. From Initialseason to Mid-season LAI increased from $0.14 \mathrm{~cm}^{2} \mathrm{~cm}^{-2}$ to $5.20 \mathrm{~cm}^{2} \mathrm{~cm}^{-2}$ in 2008 and from $0.18 \mathrm{~cm}^{2} \mathrm{~cm}^{-2}$ to 
Table 1. Sowing, emergence and full maturity data, growth season duration and accumulated GDD of cotton crop in Apodi-RN in 2008 and 2009

$\begin{array}{lcc} & \mathbf{2 0 0 8} & \mathbf{2 0 0 9} \\ \text { Sowing data } & 2008-\text { sep-22 } & 2009-\text { sep-01 } \\ \text { Emergence data } & 2009 \text {-sep-29 } & 2009-\text { sep-08 } \\ \text { Full maturity data } & 2009 \text {-jan-12 } & 2009-\text { dec-29 } \\ \text { Growth stage duration (days) } & 105 & 112 \\ \text { Accumulated GDD }\left({ }^{\circ} \mathrm{C}\right) & 1,499 & 1,507\end{array}$

Table 2. Rainfall (R), Irrigation (I) and average values of energy balance partitioning, evaporative fraction $(\Lambda)$ and soil water content (SWC) for each growth stages and full growth season of cotton crop at Apodi Plateau

\begin{tabular}{|c|c|c|c|c|c|c|c|c|}
\hline \multirow[t]{2}{*}{ Growth Season } & \multirow[t]{2}{*}{$\mathbf{R}$} & \multirow[t]{2}{*}{ I } & \multicolumn{3}{|c|}{ Energy balance portioning } & \multirow[t]{2}{*}{$\begin{array}{l}\Lambda \\
-\end{array}$} & \multirow[t]{2}{*}{$\begin{array}{c}\text { LAI } \\
\mathrm{cm}^{2} \mathrm{~cm}^{-2}\end{array}$} & \multirow[t]{2}{*}{$\begin{array}{c}\text { SWC } \\
\mathrm{cm}^{3} \mathrm{~cm}^{-3}\end{array}$} \\
\hline & & & LE/Rn & G/Rn & H/Rn & & & \\
\hline Initial & 0.0 & 120.0 & 58 & 13 & 29 & 0.68 & 0.14 & 0.223 \\
\hline Development & 0.0 & 196.1 & 75 & 14 & 11 & 0.83 & 1.10 & 0.240 \\
\hline Middle & 0.0 & 440.0 & 81 & 8 & 11 & 0.87 & 5.20 & 0.248 \\
\hline Late & 0.0 & 135.9 & 75 & 9 & 16 & 0.75 & 4.70 & 0.184 \\
\hline Full growth season & 0.0 & 892.0 & 72 & 11 & 17 & 0.78 & - & 0.224 \\
\hline Initial & 0.0 & 190.0 & 63 & 15 & 22 & 0.78 & 0.18 & 0.232 \\
\hline Development & 0.0 & 214.1 & 74 & 14 & 12 & 0.82 & 1.12 & 0.242 \\
\hline Middle & 0.0 & 350.0 & 81 & 6 & 13 & 0.84 & 5.28 & 0.244 \\
\hline Late & 18.6 & 129.9 & 76 & 7 & 17 & 0.78 & 4.80 & 0.181 \\
\hline Full growth season & 18.6 & 884.0 & 74 & 10 & 16 & 0.82 & - & 0.228 \\
\hline
\end{tabular}

$5.28 \mathrm{~cm}^{2} \mathrm{~cm}^{-2}$ in 2009 , while percentage of Rn converted into $\mathrm{LE}(\mathrm{LE} / \mathrm{Rn})$ increased from $58 \%$ to $81 \%$ in 2008 and from $63 \%$ to $81 \%$ in 2009 , in that period. On the other hand, from Mid-season to Late-season LAI decreased from $5.20 \mathrm{~cm}^{2} \mathrm{~cm}^{-2}$ to $4.70 \mathrm{~cm}^{2} \mathrm{~cm}^{-2}$ in 2008 and from $5.28 \mathrm{~cm}^{2}$ $\mathrm{cm}^{-2}$ to $4.80 \mathrm{~cm}^{2} \mathrm{~cm}^{-2}$ in 2009 , while LE/Rn decreased from $81 \%$ to $75 \%$ in 2008 and from $81 \%$ to $76 \%$ in 2009 . These decreases of both LAI and LE/Rn from Mid-season to Late-season occurred due to irrigation interruption and crop senescence. The irrigation interruption is detected by the soil water content (SWC) which during late-season was the minimum among the growth stages. According to Zhou et al. (2012) this agreement between LE/Rn and LAI is expected because high LAI largely increased transpiration, contributing then for higher $\mathrm{LE} / \mathrm{Rn}$ values and vice versa.

In contrast, the percentages of $\mathrm{Rn}$ converted into $\mathrm{G}$ $(\mathrm{G} / \mathrm{Rn})$ and $\mathrm{H}(\mathrm{H} / \mathrm{Rn})$ varied inversely with LAI and LE/ $\mathrm{Rn}$, i.e., decreases from Initial-season to Mid-season and increases from Mid-season to Late-season. This behavior is physically expected, since those values of $\mathrm{LE}$ and $\mathrm{H}$ fluxes are controlled by soil water availability (Shen et al., 2004). On the other hand, $G$ values are controlled by soil water availability and ground cover. Note that as the SWC and LAI increased, G values decreased. The lower values of G occurred during Mid-season, when LAI $>3$.

The largest values of LE/Rn observed during Mid-season is an expected result because this is the period in which the crop reaches higher foliar area providing full soil cover, i.e., when LAI>3 (Table 2). The crop is in its vigorous physiological and metabolic functions, because it is the flowering and boll formation period, requiring greatest water consumption (Allen et al., 1998).

The interannual difference between values of $L E / R n$ of each growing season was not significant statically at level $1.0 \%(\mathrm{p}<0.01)$, according to $\mathrm{t}$-Test. The similarity of the $\mathrm{LE} / \mathrm{R} n$ values of each growing season between years suggests that crop practices and irrigation management to which the crop has been submitted were similar. Although there was no significant difference between LE/Rn of each growing season of 2008 and 2009, note a higher difference of 5\% between $\mathrm{LE} / \mathrm{Rn}$ values observed during the initial growing stages of 2008 and 2009 years. This occurred because there was an error in the irrigation scheduling during one week, which was detected and corrected according to the procedure reported by Bezerra et al. (2012). The effects of excessive irrigation are also evidenced by the values of SWC and $\Lambda$, which presented values higher during 2009 in relation to 2008 campaign. The $\Lambda$ values reflect the condition of moisture in the root zone so that there is a direct relationship between them (Scott et al., 2003). It is important to note that $\mathrm{LE} / \mathrm{Rn}$ for full growth season of cotton was higher than $70 \%$, corroborating to Suyker \& Verma (2008). Ham et al. (1991) reported values about $78 \%$ for cotton crop near to Lubbock, Texas.

The percentage of $R n$ converted into $G(G / R n)$ is an important element in this analysis because the accuracy of Bowen 
ratio method depends substantially on the representativeness of their measurements according to Allen et al. (2011). In this work the soil heat flux plates were carefully installed one between rows and the other between plants in order to minimize errors, taking a more representative measurement possible. In each growth season the Rn converted into $\mathrm{G}$ presents enough similarities to ensure representativeness of their measurements. The average values of $G$ observed in both the experimental campaigns were about $10 \%$, and is similar to majority of values found for cotton crop at Texas by Ham et al. (1991).

Figure 3 shows the diurnal average of energy balance components of cotton crop during full growth stages. The maximum value of $\mathrm{Rn}$ and LE occurred around 11:30 local time (Figure 3). This is an expected behavior because these fluxes follow the daytime course of solar radiation. This similarity between daily courses of these fluxes has been used by many authors to develop models to estimate $\mathrm{Rn}$ from solar radiation.

The maximum values of $\mathrm{G}$, unlike $\mathrm{Rn}$ and LE, occurred at about 10:20 local time in 2008 and at 10:00 h local time in 2009 (Figure 3). The peak values of $\mathrm{G}$ occurred earlier in comparison with the other components due to irrigation. The influence of irrigation on $G$ has been related in the

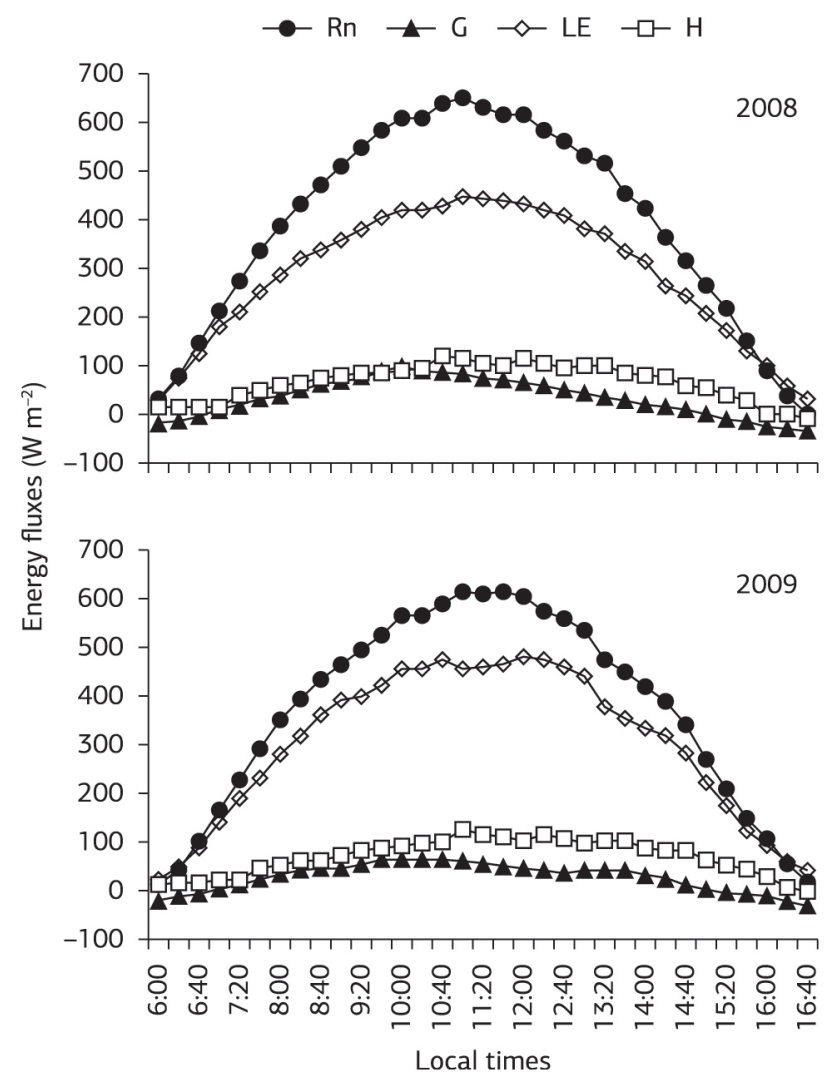

Figure 3. Daily averages of the energy balance components during the growing season of cotton crop in 2008 (above) and 2009 (below): net radiation $(\mathrm{Rn})$; latent heat flux (LE); sensible heat flux $(\mathrm{H})$ and soil heat flux $(\mathrm{G})$. literature (i.e., Abu-Hamdeh \& Reeder, 2000). The events of irrigation always occurred during the nighttime. Thus, in the morning the SWC always was higher than in the afternoon. According to Abu-Hamdeh \& Reeder (2000) increasing the SWC at a given bulk density increases the thermal conductivity, and consequently increases rate of $G$. From about 10:00 h local time the SWC decreases because of soil evaporation and loss by downward flux results in decease of $\mathrm{G}$.

The seasonal cotton ET was 716 and $754 \mathrm{~mm}$ in 2008 and 2009, respectively. These results are within the range of values reported by Azevedo et al. (1993) $(440 \mathrm{~mm})$, Bezerra et al. (2010) (543 mm), Farahani et al. (2008) $(878 \mathrm{~mm})$, Howell et al. (2004) $(757 \mathrm{~mm})$, and Zhou et al (2012) (538 mm). However, comparison of these values with other studies is difficult because the ET values are influenced by numerous local factors such as weather, soil characteristics, crop practices, water management, length of growth season, and strongly responds to the magnitude of incoming solar radiation (Alberto et al., 2011; Bezerra et al., 2012).

The daily values of ET obtained in 2008 and 2009 are showed in figure 4 . The maximum daily values of ET were $9.3 \mathrm{~mm} \mathrm{~d}^{-1}$ in 2008 and $9.6 \mathrm{~mm} \mathrm{~d}^{-1}$ in 2009 . Both values occurred during the middle of growing season, whose ratio $\mathrm{ET} / \mathrm{ET}_{0}$ or crop coefficient was 1.11 and 1.20 for 2008 and 2009, respectively. Bezerra et al. (2010) reported values of only $5.9 \mathrm{~mm} \mathrm{~d}^{-1}$ in Barbalha, southern part of Ceará state while Azevedo et al. (1993) reported values equal to $6.4 \mathrm{~mm} \mathrm{~d}^{-1}$ in the Valleys of Souza, western part of Paraiba state. Both studies were performed in the Brazilian semiarid region. These differences between maximum daily ET values presented in the current study and the values found in other areas of Brazilian semiarid can be associated to several factors such as high spatial variability of the climate parameters (relative humidity, wind speed, and air temperature) in the

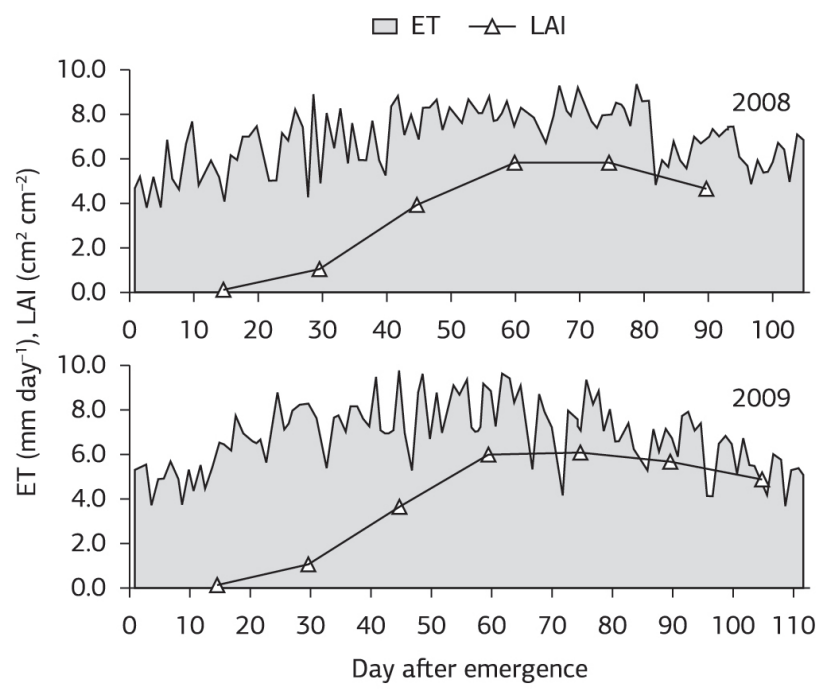

Figure 4. Seasonal variation of ET and LAI during growing seasons of 2008 and 2009. 


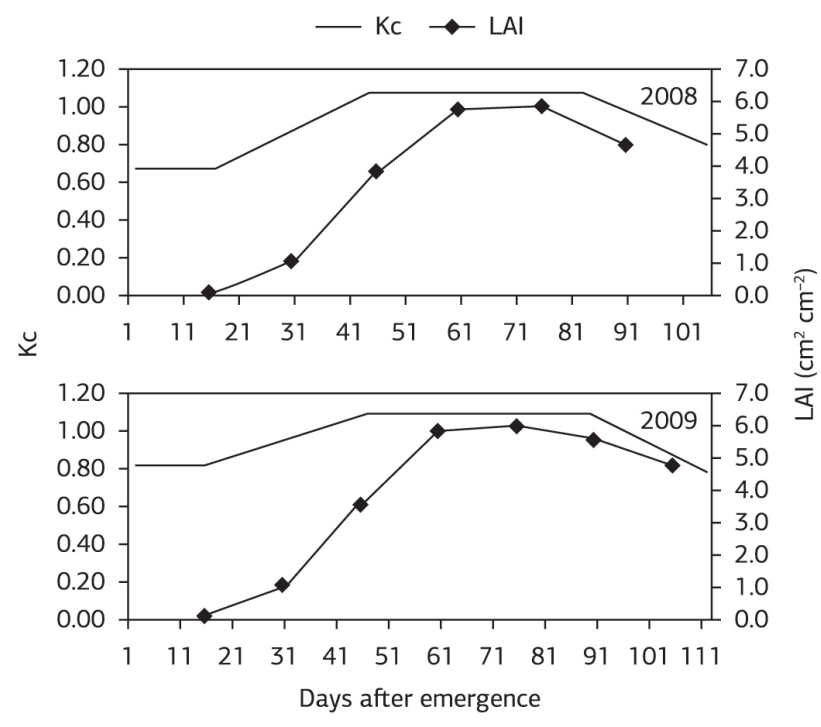

Figure 5. Crop coefficient or ET/ET 0 ratio and leaf area index (LAI) curves.

region. Another factor that possibly may have influenced this difference is the irrigation system used. In this study we used the sprinkler irrigation system where as Azevedo et al. (1993) used the furrow irrigation system.

Note that the daily values vary considerably. These variations (peak of ET values) can be attributed to heavy wetting provided by sprinkler irrigation system. The use of sprinkler irrigation causes increase in the ET on the days that occurred irrigation event. The peaks of ET values occurred on days which succeed irrigation events while lowest daily values of ET occurred on days on which there were no irrigations. The maximum daily values of ET (peaks) occurs due to increase of the soil evaporation, mainly during initial and crop-development stages when the crop do not provide full ground cover (LAI $<3$, Table 2 and Figure 5), direct evaporation of rainfall or irrigation intercepted by plant canopy, and crop residues which occur for a very small period following sprinkler irrigation (López-Urrea et al., 2009a; Odhiambo \& Irmak, 2012).

From sowing to about 60 days after emergence (DAE) ET increased continuously its daily values. This increase occurs due to crop growth in this period which is evidenced by LAI which increased from $0.14 \mathrm{~cm}^{2} \mathrm{~cm}^{-2}$ (15 DAE) to $5.80 \mathrm{~cm}^{2} \mathrm{~cm}^{-2}$ (60 DAE) in 2008 and from $0.18 \mathrm{~cm}^{2} \mathrm{~cm}^{-2}$ to $5.90 \mathrm{~cm}^{2} \mathrm{~cm}^{-2}$, during the same period in 2009 (Figure 4). From $60 \mathrm{DAE}$ to end of the growth seasons LAI and ET decreased due to crop senescence. However, this temporal pattern of ET over each cotton growing season is comparable to the trend described in FAO-56 (Allen et al., 1998).

Note that there is a similarity between the behavior of ET and LAI curves. To examine the dependence of ET on LAI Suyker \& Verma (2008) normalized the measured daily $\mathrm{ET}$ of soybean and maize with $\mathrm{ET}_{0}$, i.e., $\mathrm{ET} \mathrm{ET}_{0}$ or crop coefficient $(\mathrm{Kc})$, and plotted the ratio as a function of LAI (Figure 5). The result showed a nearly linear relationship. According to Steduto \& Hsiao (1998), this similarity exists because there is a nearly linear dependence of ET/ $\mathrm{ET}_{0}$ or Kc until a certain threshold LAI, generally between 3 and 4 . The relationship between Kc curves, which was constructed based on FAO-56 methodology (Allen et al., 1998; Bezerra et al., 2012), and LAI curves of this study is shown in figure 5. The relationship corroborates with Steduto \& Hsiao (1998) because as can be seen the concordance between both the curves becomes narrower from $45 \mathrm{DAE}$, i.e., when LAI reaches values higher than 3. This apparent strong agreement is maintained until the end of growth season, corroborating to Suyker \& Verma (2008), which affirms that this dependence occurs during periods of leaf expansion and canopy senescence.

The strong agreement between Kc and canopy parameters such as LAI, vegetation indices, and ground cover fraction provided by canopy is already known in literature for different crops such as spring wheat (López-Urrea et al., 2009b), soybean (Odhiambo \& Irmak, 2012), cotton (Hunsaker et al., 2003) and has been used to estimate ET of agricultural fields based on these relationships (Hunsaker et al., 2003; Simoneaux et al., 2008).

\section{CONCLUSION}

Energy balance partitioning of cotton crop under full irrigation conditions in the Brazilian semiarid was observed during two successive seasons. The seasonal variations of energy balance partitioning and its relations with vegetative growth were discussed.

Over 2-seasons, LE/Rn values were higher than 70\%, G/Rn about $10 \%$ and $H / R n$ equal to $17 \%$ in 2008 and $16 \%$ in 2009 . The results revealed important role of the vegetative growth of cotton crop in the energy balance partitioning. The values of $\mathrm{LE} / \mathrm{Rn}$, varied in accordance with LAI variations, while $H / R n$ and $G / R n$ varied inversely with LAI changes along cop growth seasons. The concordance between LE/Rn and LAI is also evidenced by similarity between curves of ET and LAI and between curves of Kc and LAI, mainly when the cotton crop reached full ground cover (i.e., when LAI > 3).

\section{ACKNOWLEDGEMENTS}

The authors gratefully acknowledge CNPq for supporting this research, accord ATECEL-FINEP-EMBRAPA n. ${ }^{\circ}$ 591-07, and to CNPq/CT-HIDRO for the doctoral scholarship of the first author. 


\section{REFERENCES}

Abu-Hamdeh, N. H., \& Reeder, R. C. (2000). Soil thermal conductivity: effects of density, moisture, salt concentration, and organic matter. Soil Science Society of America Journal, 64, 1285-1290. http://dx.doi. org/10.2136/sssaj2000.6441285x.

Alberto, M. C. R., Wassmann, R., Hiranol, T., Miyata, A., Hetano, R., Kumar, A., Padre, A., \& Amante, M. (2011). Comparisons of energy balance and evapotranspiration between flooded and aerobic Rice fields in the Philippines. Agricultural Water Management, 98, 1417-1430. http://dx.doi.org/10.1016/j.agwat.2011.04.011.

Allen, R., Pereira, L. S., Raes, D., \& Smith, M. (1998). Crop evapotranspiration, guidelines for computing crop water requirements. Rome: Paper No. 56.

Allen, R. G., Pereira, L. S., Howell, T. A., \& Jensen, M. E. (2011). Evapotranspiration information reporting: I. Factors governing measurement accuracy. Agricultural Water Management, 98, 899920. http://dx.doi.org/10.1016/j.agwat.2010.12.015.

Azevedo, P. V., Rao, T. V. R., Amorim, M. S., No., Bezerra, J. R. C., Espínola, J., So., \& Maciel, G. F. (1993). Necessidades hídricas da cultura do algodoeiro. Pesquisa Agropecuaria Brasileira, 28, 863-870.

Baldocchi, D. (2003). Assessing the eddy covariance technique for evaluating carbon dioxide exchange rates of ecosystems: past, present and future. Global Change Biology, 9, 479-492. http://dx.doi. org/10.1046/j.1365-2486.2003.00629.x.

Bezerra, B. G., Silva, B. B., Bezerra, J. R. C., Sofiatti, V., \& Santos, C. A. C. (2012). Evapotranspiration and crop coefficient for sprinkler-irrigation cotton crop in Apodi Plateau semiarid lands of Brazil. Agricultural Water Management, 107, 86-93. http://dx.doi. org/10.1016/j.agwat.2012.01.013.

Bezerra, J. R. C., Azevedo, P. V., Silva, B. B., \& Dias, J. M. (2010). Evapotranspiração e coeficiente de cultivo do algodoeiro BRS-Marrom, irrigado. Revista Brasileira de Engenharia Agrícola e Ambiental, 14, 625-632. http://dx.doi.org/10.1590/S1415-43662010000600009.

Bowen, I. S. (1926). The ratio of heat losses by conduction and by evaporation from any water surface. Physical Review, 27, 779-787. http://dx.doi.org/10.1103/PhysRev.27.779.

Brutsaert, W. (1982). Evaporation into the Atmosphere. Dordrecht: D Reidel Publishing Company.. http://dx.doi.org/10.1007/978-94017-1497-6.

Centro Nacional de Pesquisa do Algodão - CNPA. (2000). BRS 187 8H: Nova cultivar de algodoeiro herbáceo para as condiçóes do Nordeste. Campina Grande: EMBRAPA.

Farahani, H. J., Oweis, T. Y., \& Izzi, G. (2008). Crop coefficient for drip-irrigated cotton in a Mediterranean environment. Irrigation Science, 26, 375-383. http://dx.doi.org/10.1007/s00271-007-0101-0.

Ham, J. M., Heilman, J. L., \& Lascano, R. J. (1991). Soil and canopy energy balances of a row crop at partial cover. Agronomy Journal, 83, 744-753. http://dx.doi.org/10.2134/agronj1991.00021962008 $300040019 x$.

Howell, T. A., Evett, S. R., Tolk, J. A., \& Schneider, D. A. (2004). Evapotranspiration of full-, deficit-irrigated, and dryland cotton on the Northern Texas high plains. Journal of Irrigation and Drainage Engineering, 130, 277-285. http://dx.doi.org/10.1061/(ASCE)07339437(2004)130:4(277).

Hunsaker, D. J., Pinter, P. J., Jr., Barnes, E. M., \& Kimball, B. A. (2003). Estimating cotton evapotranspiration crop coefficients with a multispectral vegetation index. Irrigation Science, 22, 95-104. http:// dx.doi.org/10.1007/s00271-003-0074-6.

López-Urrea, R., Montoro, A., López-Fuster, P., \& Fereres, E. (2009a). Evapotranspiration and responses to irrigation of broccoli. Agricultural Water Management, 96, 1155-1161. http://dx.doi.org/10.1016/j. agwat.2009.03.011.

López-Urrea, R., Montoro, A., González-Piqueras, J., López-Fuster, P., \& Fereres, E. (2009b). Water use of spring wheat to raise water productivity. Agricultural Water Management, 96, 1305-1310. http:// dx.doi.org/10.1016/j.agwat.2009.04.015.

Mavi, H. S., \& Tupper, G. J. (2004). Agrometeorology: principles and application of climate studies in agriculture. New York: Food Products Press.

Odhiambo, L. O., \& Irmak, S. (2012). Evaluation of the impact of surface residue cover on single and dual crop coefficient for estimating soybean actual evapotranspiration. Agricultural Water Management, 104, 221-234. http://dx.doi.org/10.1016/j.agwat.2011.12.021.

Payero, J. O., Neale, C. M. U., Wright, J. L., \& Allen, R. G. (2003). Guidelines for Validating Bowen Ratio Data. Transactions of the ASAE. American Society of Agricultural Engineers, 46, 1051-1060. http://dx.doi.org/10.13031/2013.13967.

Peacock, C. E., \& Hess, T. M. (2004). Estimating evapotranspiration from a reed bed using the Bowen ratio energy balance method. Hydrological Processes, 18, 247-260. http://dx.doi.org/10.1002/ hyp. 1373 .

Perez, P. J., Castellvi, F., Ibañez, M., \& Rosell, J. I. (1999). Assessment of reliability of Bowen ratio method for partitioning fluxes. Agricultural and Forest Meteorology, 97, 141-150. http://dx.doi.org/10.1016/ S0168-1923(99)00080-5.

Scott, C. A., Bastiaanssen, W. G. M., \& Ahmad, M. D. (2003). Mapping root zone soil moisture using remotely sensed optical imagery. Journal of Irrigation and Drainage Engineering, 129, 326-335. http://dx.doi. org/10.1061/(ASCE)0733-9437(2003)129:5(326).

Shen, Y., Zhang, Y., Kondoh, A., Tang, C., Chen, J., Xiao, J., Sakura, Y., Liu, C., \& Sun, H. (2004). Seasonal variation of energy partitioning in irrigated lands. Hydrological Processes, 18, 2223-2234. http:// dx.doi.org/10.1002/hyp.5535.

Simonneaux, V., Duchemin, B., Helson, D., Er-Raki, S., Olioso, A., $\&$ Chehbouni, A. G. (2008). The use of high-resolution image time series for crop classification and evapotranspiration estimate over an irrigated area in central Morocco. International Journal of Remote Sensing, 29, 95-116. http://dx.doi.org/10.1080/01431160701250390.

Steduto, P., \& Hsiao, T. C. (1998). Maize canopies under two soil water regimes II. Seasonal trends of evapotranspiration, carbon dioxide assimilation and canopy conductance, and as related to leaf area index. Agricultural and Forest Meteorology, 89, 185-200. http:// dx.doi.org/10.1016/S0168-1923(97)00084-1. 
Suyker, A. E., \& Verma, S. B. (2008). Interannual water vapor and energy exchange in an irrigated maize-based agroecosystem. Agricultural and Forest Meteorology, 148, 417-427. http://dx.doi.org/10.1016/j. agrformet.2007.10.005.

Teixeira, A. H. C., \& Bastiaanssen, W. G. M. (2012). Five methods to interpret field measurements of energy fluxes over a micro-sprinkler- irrigated mango orchard. Irrigation Science, 30, 13-28. http://dx.doi. org/10.1007/s00271-010-0256-y.

Zhou, S., Wang, J., Liu, J., Yang, J., Xu, Y., \& Li, J. (2012). Evapotranspiration of a drip-irrigated film-mulched cotton field in northern Xinjiang, China. Hydrological Processes, 26, 1169-1178. http://dx.doi.org/10.1002/hyp.8208. 